\title{
Хірургічне лікування поєднаної патологї анального каналу і прямої кишки з використанням сучасних високочастотних електрохірургічних та радіохірургічних апаратів
}

\author{
М. П. Захараш ${ }^{1}$, В. В. Балицький ${ }^{2,3}$, О. Г. Курик ${ }^{4}$ \\ ${ }^{1}$ Національний медичний університет імені О. О. Богомольця, м. Київ, \\ ${ }^{2}$ Вінницький національний медичний університет імені М. І. Пирогова, \\ ${ }^{3}$ Хмельницька обласна лікарня,
}

4Науково-практичний центр профілактичної та клінічної медицини ДУС, м. Київ

\section{Surgical treatment of coexistent pathology of anal channel and rectum, using a modern high-frequency electro-surgical and radio-surgical apparatuses}

\author{
M. P. Zakharash ${ }^{1}$, V. V. Balytskyy ${ }^{2,3}$, O. G. Kuryk ${ }^{4}$ \\ 'Bogomolets National Medical University, Kyiv, \\ ${ }^{2}$ National Pirogov Memorial Medical University, Vinnytsya, \\ ${ }^{3}$ Khmelnytskyi Regional Hospital, \\ ${ }^{4}$ Scientific-Practical Centre of Prophylactic and Clinical Medicine, Kyiv
}

Реферат

Мета. Покращення результатів хірургічного лікування пацієнтів з поєднаною патологією анального каналу (АК) і прямої кишки (ПК) шляхом застосування високочастотних (ВЧ) електрохірургічних (EX) апаратів «ERBE ICC 200», «EФA», «KLS Martin» та апарата радіохвильової (PX) хірургії «Surgitron» і їх порівняльна характеристика.

Матеріали і методи. Проаналізовані результати лікування 564 пацієнтів 3 поєднаною патологією АК і ПК з використанням ВЧ ЕX апаратів «ERBE ICC 200», «ЕФA», «KLS Martin» та апарата PX хірургії «Surgitron».

Результати. Дослідженням встановлено, що застосування ВЧ ЕX апаратів «ЕRВЕ ICC 200», «ЕФА», «KLS Martin» та aпарата PX хірургії «Surgitron» зменшує тривалість операції до (20 \pm 5) хв, об’єм інтраопераційної крововтрати до (20 \pm 10$)$ мл,

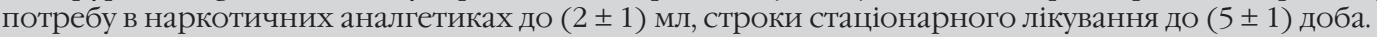

Висновки. Використання ВЧ ЕX апаратів «ERBE ICC 200», «ЕФA», «KLS Martin» та апарата PX хірургї̈ «Surgitron» забезпечує скорочення тривалості операції, зменшення об'єму крововтрати під час операції, інтенсивності больового синдрому в післяопераційному періоді, а також незначну глибину некрозу тканин (від 0,055 до 0,43 мм), що обумовлює хороший косметичний результат операції.

Ключові слова: високочастотні електрохірургічні апарати «ERBE ICC 200»; «ЕФA» «KLS Martin»; апарат радіохвильової хірургії «Surgitron»; поєднана патологія; анальний канал; пряма кишка.

Abstract

Objective. Improvement of results of surgical treatment in patients with coexistent pathology of anal channel (ACH) and rectum, using high-frequency (HF) electrosurgical (ES) apparatuses «ERBE ICC 200», «EFA», «KLS Martin», and apparatus of a radio-wave (RW) surgery «Surgitron» and studying of their comparative characteristics.

Materials and methods. Results of treatment were analyzed in 564 patients with coexistent pathology of ACH and rectum, using a HF ES with apparatuses «ERBE ICC 200», «EFA», «KLS Martin» and apparatus of the RW surgery «Surgitron».

Results. There was established in the investigation, that application of the HF ES apparatuses «ERBE ICC 200», «EFA», «KLS Martin» and apparatus of RW surgery «Surgitron» reduces the operation duration to $(20 \pm 5)$ min, volume of intraoperative blood loss - to $(20 \pm 10) \mathrm{ml}$, necessity in narcotic analgetics - to $(2 \pm 1) \mathrm{ml}$, terms of stationary treatment - to $(5 \pm 1)$ days.

Conclusion. Application of the HF ES apparatuses «ERBE ICC 200», «EFA», «KLS Martin» and apparatus of RW surgery «Surgitron» guarantees the operation duration shortening, reduction of the intraoperative blood volume as well as the intensity of the pain syndrome in postoperative period, and nonsignificant depth of the tissues necrosis (from 0.055 to $0.43 \mathrm{~mm}$ ) as well, providing good cosmetic result of operation.

Keywords: a high-frequency electrosurgical apparatuses «ERBE ICC 200»; «EFA», «KLS Martin»; apparatus of a radio-wave surgery «Surgitron»; coexistent pathology; anal channel; rectum. $\Phi$

У структурі проктологічних захворювань питома вага поєднаної патології АК і ПК становить від 35 до 65\% та невпинно зростає [1]. Прогресивний розвиток сучасних технологій сприяв активному впровадженню у практику колопроктологів нових методів хірургічного лікування аноректальної патології. Зокрема, у лікуванні геморою широко використовують електротермічну систему «Liga
Sure» для коагуляції і пересічення судин діаметром до 7 мм, що забезпечує ретельний гемостаз, скорочує тривалість операції, оскільки немає необхідності виділення та лігування судинної ніжки гемороїдального вузла. Але даний метод лікування не позбавлений ряду недоліків: частота виникнення післяопераційної кровотечі становить 2,1 7,1\%, дизуричних розладів - 5 - 6,4\%, вираженого больо- 
вого синдрому - 7,6 - 11,7\% [2, 3]. Після застосування ультразвукового скальпеля для лікування аноректальної патології, що уможливлює виконання оперативних втручань без прошивання судин з мінімальним термічним впливом на тканини АК, у результаті чого зменшується тривалість операції та об'єм інтраопераційної крововтрати [4], частота виникнення післяопераційної кровотечі коливається в межах від 2 до 4\%, у зв'язку з чим виникає потреба прошивання кровоточивих ділянок, виражений больовий синдром констатують у 5\% пацієнтів, тенезми - у 10\%, тривале загоєння післяопераційної рани - у 6\% [5].

32005 р. у лікуванні анальних тріщин та хронічного геморою широко використовують лазерні технології. Застосовуючи «лазерний скальпель», дія якого базується на прямому механічному впливі високоінтенсивного випромінювання, розрізають та «зварюють» тканини. Лазерне випромінювання інфрачервоної частини спектра має ряд переваг: малотравматичність виконання операцій у підслизовому шарі без накладання швів, мінімізація больових відчуттів у післяопераційному періоді, менші запальні зміни в післяопераційній рані, скорочення строків тимчасової непрацездатності на 2 - 3 доби [6, 7]. Водночас дослідженнями щодо застосування лазера для гемороїдектомії отримано дані про тривале загоєння післяопераційної рани, що, вірогідно, пов'язано з неконтрольованою глибиною термічного впливу до 4,2 мм, та необхідність додаткового прошивання великих судин. Також відомо, що у разі використання вуглекислотних лазерів гемостаз за наявності крові в операційній рані недостатній, інфрачервона енергія прямо проникає в тканину, спричиняючи iї перегрів [8].

Серед мініінвазивних методів лікування аноректальної патології дедалі частіше застосовують лазерну вапоризацію анальної фістули та навколишніх тканин, перевагами якої є мінімізація больового синдрому в післяопераційному періоді, швидка епітелізація ран, а також можливість застосування в амбулаторних умовах. Але після цього методу лікування частота виникнення рецидиву анальної фістули впродовж спостереження від 1 до 3 років становить $3,4-13,3 \%[8,9]$.

У 2007 р. тайський професор A. Rojanasakul запропонував методику LIFT (ligation of intersphincteric fistula tract), яка, за його даними, є ефективною більше ніж у 90\% пацієнтів незалежно від типу нориці. На жаль, ця методика супроводжується виникненням рецидиву у 16,6 - 55,6\% хворих, а у разі ії застосування в лікуванні транссфінктерних та екстрасфінктерних нориць ПК виникає інтрасфінктерна нориця, яка потребує повторного оперативного втручання [10].

Впровадження в клінічну практику відеоендоскопічних технологій стало передумовою для розробки італійським хірургом Р. Meinero у 2011 р. мініінвазивного високотехнологічного методу лікування нориць ПК VAAFT (Video Assisted Anal Fistula Treatment), який передбачає ушивання внутрішнього отвору нориці, фістулоскопію норицевого ходу з коагуляцією ділянок, які кровоточать після очистки його від сполучної тканини, та прошивання слизової оболонки в ділянці попередньо ушитого внутрішнього отвору за допомогою лінійного або горизон- тального степлера для надійної герметизації внутрішнього отвору нориці [11]. Хоча це новітня технологія, але після iі застосування частота виникнення рецидиву нориці становить 12 - 16\% [12].

Отже, актуальними є розробка та впровадження в клінічну практику нових високоефективних методів хірургічного лікування поєднаної патології АК і ПК, а також створення сучасних алгоритмів лікування цієї патології, які б забезпечували перебіг післяопераційного періоду без виникнення рецидивів та недостатності анального сфінктера і швидку медико-соціальну реабілітацію пацієнтів.

Мета дослідження: покращення результатів хірургічного лікування пацієнтів з поєднаною патологією АК і ПК шляхом застосування ВЧ ЕX апаратів «ERBE ICC 200», «ЕФA», «KLS Martin» та апарата PX хірургіï «Surgitron» i ïx порівняльна характеристика.

\section{Матеріали і методи дослідження}

Із січня 2007 по серпень 2018 р. у відділенні проктології Хмельницької обласної лікарні оперували 564 пацієнти з поєднаною патологією АК і ПК з використанням ВЧ EX апаратів «ERBE ICC 200», «ЕФA», «KLS Martin» та апарата PX хірургії «Surgitron» (досліджувана група). Чоловіків було 328 (58,15\%), жінок - 236 (41,85\%). Вік пацієнтів коливався від 18 до 76 років.

У досліджуваній групі з використанням апарата PX хірургіï «Surgitron» оперували 236 (41,8\%) пацієнтів, ВЧ ЕХ апаратів «ERBE ICC 200» - 164 (29,1\%), «EФA» - 114 (20,2\%) «KLS Martin» $-50(8,9 \%)$.

Контрольну групу склали 112 пацієнтів з поєднаною патологією АК і ПК, яких оперували стандартно з використанням хірургічного металевого скальпеля. Всі оперативні втручання виконані під спинномозковою анестезією.

Всім пацієнтам перед операцією проведено огляд періанальної і параректальних ділянок, виконано пальцеве дослідження АК і ПК, ректороманоскопію, а також 3 метою дообстеження і виключення патології ободової кишки 200 (35,5\%) пацієнтам у віці старше 45 років - іригоскопію або фіброколоноскопію.

Після оперативних втручань з використанням апарата PX хірургіï «Surgitron», а також ВЧ ЕX апаратів «ЕRBE ICC 200», «ЕФA», «KLS Martin» проводили морфологічне дослідження тканин з метою визначення глибини їх некрозу, а для порівняння використовували операційний матеріал після застосування хірургічного металевого скальпеля.

Операційний матеріал фіксували у 10\% розчині нейтрального формаліну, далі його обробляли в гістопроцесорі карусельного типу STP-120. Для виготовлення парафінових блоків використовували станцію ЕС-350, парафінових зрізів - ротаційний мікротом серії НM - 340Е, для фарбування гістологічних препаратів - автомат RobotStainer HMS-740 (всі апарати фірми Carl Zeiss MICROM International $\mathrm{GmbH}$ ). Препарати фарбували гематоксиліном і еозином. Використовували мікроскоп Axioskop 40 з фотокамерою Axio Cam MRc5 (Karl Zeiss).

\section{Результати}

Під час дослідження було встановлено, що 422 (74,8\%) пацієнти мали два захворювання АК і ПК, 126 (22,3\%) - 
три, 15 (2,7\%) - чотири, 1 (0,2\%) - п'ять. Також було виявлено 53 варіанти поєднаної патології АК і ПК, серед яких найчастіше констатували такі: хронічна анальна тріщина і анальний поліп - у 93 (16,5\%) пацієнтів, хронічна анальна тріщина і комбінований геморой - у 71 (12,6\%), комбінований геморой і хронічний парапроктит - у 56 (9,9\%), комбінований геморой і анальний поліп - у 50 (8,9\%), зовнішній геморой і анальний поліп - у 22 (3,9\%), комбінований геморой, хронічна анальна тріщина і анальний поліп - у 20 (3,5\%), хронічна анальна тріщина, анальний поліп і гіпертрофовані періанальні шкірні мітки - у 18 (3,2\%), анальний поліп і гіпертрофовані періанальні шкірні мітки - у 17 (3\%), зовнішній геморой і хронічна анальна тріщина - у 16 (2,8\%), хронічний парапроктит і анальний поліп - у 16 (2,8\%), зовнішній геморой і хронічний парапроктит - у 15 (2,7\%), зовнішній геморой, хронічна анальна тріщина і анальний поліп - у 10 (1,8\%), хронічний внутрішній геморой III стадії і хронічна анальна тріщина - у 9 (1,6\%), хронічна передня, хронічна задня анальні тріщини і анальний поліп - у 7 (1,2\%), хронічна анальна тріщина і гіпертрофовані анальні сосочки - у 7 (1,2\%).

Характер виконаних оперативних втручань залежав від варіанта поєднаної патології АК і ПК. Висічення анальної тріщини і поліпектомію виконали 93 (16,5\%) пацієнтам, гемороїдектомію і поліпектомію - 72 (12,8\%), висічення анальної тріщини і гемороїдектомію - 71 (12,6\%), гемороїдектомію і висічення анальної фістули 65 (11,5\%), гемороїдектомію, висічення анальної тріщини і поліпектомію - 30 (5,3\%), гемороїдектомію і висічення анальної тріщини - 25 (4,4\%), висічення анальної тріщини, поліпектомію та електроексцизію гіпертрофованої періанальної шкірної мітки - 18 (3,2\%), поліпектомію та електроексцизію гіпертрофованої періанальної шкірної мітки - 17 (3\%), висічення анальної фістули і поліпектомію - 16 (2,8\%), висічення анальних тріщин і поліпектомію - 7 (1,2\%), висічення анальної тріщини і папілектомію - 7 (1,2\%).

У разі використання апарата РХ хірургіï «Surgitron» тривалість операції становила в середньому (15 \pm 5$)$ хв, ВЧ ЕХ апарата «ERBE ICC 200» - (20 \pm 5$)$ xв, «ЕФA» - (25 \pm 5$)$ xв, «KLS Martin» - $(15 \pm 5)$ хв, у контрольній групі - (30 \pm 5$)$ хв; об'єм крововтрати - відповідно (20 \pm 10$),(15 \pm 5),(20$ $\pm 5),(20 \pm 10)$ та $(40 \pm 10)$ мл. Больовий синдром у післяопераційному періоді був більш виражений у пацієнтів контрольної групи, вони потребували наркотичних засобів для знеболювання (4 \pm 1 ) мл. У досліджуваній групі пацієнти потребували для знеболювання всього $(2 \pm 1)$ мл наркотичних засобів у разі використання апарата PX xipypгiï «Surgitron» і ВЧ EX апаратів «ERBE ICC 200» $\mathrm{i}$ «KLS Martin» та (3 \pm 1$)$ мл у разі використання ВЧ ЕX апарата «ЕФА. Строки лікування у стаціонарі пацієнтів досліджуваної групи становили (4 \pm 1 ) день у разі використання апарата РX хірургіï «Surgitron» і ВЧ ЕX апарата «KLS Martin», (5 $\pm 1)$ день - ВЧ ЕX апарата «ЕRBE ICC 200», (6 1) день - ВЧ EX апарата «ЕФА». У контрольній групі строки стаціонарного лікування пацієнтів були тривалішими - (7 \pm 1$)$ день.

У післяопераційному періоді у пацієнтів досліджуваної групи не спостерігали ознак недостатності анального сфінктера та формування рубцевої стриктури АК, У контрольній групі у 2 (1,8\%) пацієнтів сформувалась ру- бцева стриктура анального каналу, яку у 1 пацієнта вилікували консервативними заходами, у 1 - оперативними.

За даними морфологічного дослідження встановлено, що у разі використання апарата РХ хірургії «Surgitron» зберігається тканинна структура з утворенням по краю розрізу шару коагуляційного некрозу (карбонізації) глибиною в середньому $(0,165 \pm 0,11)$ мм.

Під час розрізу тканин електрохірургічним методом відбувається їх розсічення і коагуляція з контролем гемостазу та утворюється шар коагуляційного некрозу глибиною в середньому $(0,286 \pm 0,15)$ мм у разі застосування ВЧ ЕХ апарата «ERBE ICC 200», $(0,254 \pm 0,18)$ мм - «ЕФА» та $(0,192 \pm 0,12)$ мм - «KLS Martin». У пацієнтів контрольної групи, яким тканини розрізали хірургічним металевим скальпелем, спостерігали механічну травматизацію і крововиливи в краях операційної рани, що в подальшому уповільнювало їі загоєння.

\section{Обговорення}

Тривалість оперативних втручань 3 приводу поєднаної патології АК і ПК із застосуванням апарата РХ хірургії «Surgitron» та ВЧ ЕХ апарата «KLS Martin» становила (15 $\pm 5)$ Хв, що втричі менше порівняно з контрольною групою. У разі застосування ВЧ ЕX апаратів «ЕRBE ICC 200» та «ЕФА» тривалість операцій була меншою вдвічі та у півтора разу відповідно порівняно з контрольною групою.

Використання апарата РX хірургіï «Surgitron» і ВЧ EX апаратів «ERBE ICC 200», «ЕФA» та «KLS Martin» для лікування хворих з поєднаною патологією АК і ПК зменшувало у 2,5 - 3 рази об'єм крововтрати під час операції у досліджуваній групі порівняно з контрольною групою.

Після застосування апарата РX хірургії «Surgitron» і ВЧ EX апаратів «KLS Martin», «ERBE ICC 200» та «ЕФА» для лікування хворих з поєднаною патологією АК і ПК утворювався шар коагуляційного некрозу в тканинах глибиною відповідно 0,055 - 0,072 та 0,074 - 0,136 мм, завдяки чому у пацієнтів досліджуваної групи больовий синдром був відповідно у 2 - 3 та 1,5- 2 рази меншим і вони потребували відповідно у 2 - 3 та 1,5 - 2 рази менше наркотичних засобів для знеболювання порівняно з контрольною групою.

Після застосування хірургічного металевого скальпеля утворювались поширені крововиливи в тканинах, що призводило до їх більшої травматизації і відповідно більш вираженого больового синдрому у пацієнтів контрольної групи.

Мінімальний вплив на тканину у разі використання апарата PX хірургії «Surgitron» і ВЧ ЕХ апаратів «ERBE ICC 200», «ЕФА» та «KLS Martin» сприяв формуванню косметичного післяопераційного рубця, запобігав виникненню рубцевих стриктур АК, що зменшувало строки загоєння ран та строки реабілітації пацієнтів досліджуваної групи.

\section{Висновки}

1. У разі використання апарата РX хірургії «Surgitron» i ВЧ ЕX апаратів «ERBE ICC 200», «ЕФА» та «KLS Martin» для лікування хворих з поєднаною патологією АК і ПК зменшуються тривалість операції у 2 - 3 рази, об'єм інтраопераційної крововтрати у $2,5-3$ рази та інтенсивність больового синдрому в післяопераційному періоді у 2-3 ра- 
зи, а також скорочуються у 2 рази терміни лікування пацієнтів, обумовлюючи їх швидшу медико-соціальну реабілітацію.

2. Застосування сучасних апарата РХ хірургії та ВЧ ЕХ апаратів має суттєво кращий ефект порівняно з використанням хірургічного металевого скальпеля, що виявляється у швидкому загоєнні післяопераційної рани завдяки формуванню тонкого шару коагуляційного некрозу з утворенням ніжного еластичного рубця без рубцевих стриктур АК та недостатності анального сфінктера в післяопераційному періоді.

\section{References}

1. Bach HH, Wang N, Eberhardt JM.Common anorectal disorders for the intensive care physician. J Intensive Care Med. 2014 Nov-Dec;29(6):33441. doi: $10.1177 / 0885066613485347$.

2. Rivadeneira DE, Steele SR, Ternent C, Chalasani S, Buie WD, Rafferty JL. Standards Practice Task Force of The American Society of Colon and Rectal Surgeons. Practice parameters for the management of hemorrhoids (revised 2010). Dis Colon Rectum. 2011 Sep;54(9): 1059-64. doi:10.1097/dcr.0b013e318225513d.

3. Bichurin NR, Ionin VP. Gemorroidjektomija s ispolzovaniem sovremennyh jelektrohirurgicheskih instrumentov. In: materialy vserossijskoj nauchno-prakticheskoj konferentsii s mezhdunarodnym uchastiem, 2017. Koloproctologia. 2017;(3): 17.[In Russian].

4. Wald A, Bharucha AE, Cosman BC, Whitehead WE. ACG clinical guideline: management of benign anorectal disorders. Am J Gastroenterol. 2014 Aug;109(8):1141-57. doi:10.1038/ajg.2014.190.

5. Lohsiriwat V. Treatment of hemorrhoids: A coloproctologist's view. World J Gastroenterol. Aug 21;21(31):9245-52. doi: 10.3748/wjg.v21. i31.9245.

6. Esfahani MN, Madani G, Madhkhan S. A novel method of anal fissure laser surgery: a pilot study. Laser Med Sci. 2015 Aug;30(6):1711-7. doi: 10.1007/s10103-015-1771-0.

7. Lohsiriwat V. Hemorrhoids: from basic pathophysiology to clinical management. World J Gastroenterol. 2012 May 7; 18(17);18:2009-17. doi: 10.3748/wjg.v18.i17.2009.

8. Lohsiriwat V. Anorectal emergencies. World J Gastroenterol. 2016 Jul 14;22(26):5867-78. doi: 10.3748/wjg.v22.i26.5867.

9. Grucela A, Salinas H, Khaitov S, Steinhagen RM, Gorfine SR, Ches$\sin$ DB. Prospective analysis of clinician accuracy in the diagnosis of benign anal pathology: comparison across specialties and years of experience. Dis Colon Rectum. 2010 Jan;53(1):47-52. doi: 10.1007/ DCR.0b013e3181bbfc89.

10. Steele SR, Kumar R, Feingold DL, Rafferty JL, Buie WD, Standards Practice Task Force of the American Society of Colon and Rectal Surgeons. Practice parameters for the management of perianal abscess and fistula-in-ano. Dis Colon Rectum. 2011 Dec;54(12):1465-74. doi: 10.1097/DCR.0b013e31823122b3.

11. Meinero P, La Torre M, Stazy A, Carbone A. Video assisted anal fistula treatment (VAAFT). In: abstracts of the $10^{\text {th }}$ Scientific and Annual Meeting of the European Society of Coloproctology. 2015.09.23-25; Dublin. Colorectal Disease. 2015;17(2):8.

12. Nelson RL, Chattopadhyay A, Brooks W, Platt I, Paavana T, Earl S. Operative procedures for fissure in ano. Cochrane database Syst Rev. 2011 Nov 9;(11):CD002199. doi: 10.1002/14651858. CD002199. 